\title{
TINJAUAN HUKUM ISLAM TERHADAP PENGELOLAAN LINGKUNGAN HIDUP DALAM UNDANG-UNDANG NO. 23 TAHUN 1997
}

\author{
Harjoni Desky \\ STAIN Malikussaleh Lhokseumawe \\ Jl. Listrik Gang Baroena Hagu Teungoh Kec. Banda Sakti Lhokseumawe \\ Email: harjonidesky(@yahoo.com
}

\begin{abstract}
Abstrak
Islam sebagai agama yang membawa rahmat bagi alam semesta, sangat peduli terhadap pengelolaan lingkungan, karena itu Islam sangat menganjurkan hubungan harmonis antara manusia dan lingkungan. Artikel ini bertujuan untuk melihat bagaimana pengelolaan lingkungan hidup ditinjau dari perspektif hukum Islam dikaitkan juga dengan Undang-Undang No. 23 Tahun 1997 tentang Pengelolaan Lingkungan. Melalui metode deskriptif, artikel ini akan menjelaskan urgensi pengelolaan lingkungan dari versi hukum Islam dan hukum positif di Indonesia. Melalui UU tersebut, hukum positif di Indonesia menerapkan tindakan pidana bagi penyalahgunaan dan perusakan lingkungan hidup. Demikian juga Islam mengharamkan orang berbuat kerusakan di bumi, dan para ulama menetapkan hukuman ta'zir untuk perusak lingkungan. Berdasarkan pendapat para ulama' ini, maka dapat ditarik suatu kesimpulan bahwa penetapan pidana bagi perusak lingkungan dalam hukum positif sejalan dengan ketentuan ta'zir dalam hukum Islam.
\end{abstract}

Kata kunci: pengelolaan, lingkungan hidup, hukum Islam, UU No. 23/1997, hukuman

\begin{abstract}
Islam as a religion that brings blessing for the universe very concerns about environmental management, therefore Islam strongly encourages harmonious relationship between human beings and the environment. This article aims to look at how environmental management is reviewed from the perspective of Islamic law and it is also associated with the Law No. 23/1997 on Environmental Management. Through a descriptive method, this article will explain the urgency of the environmental management from the perspective of Islamic law and positive law in Indonesia. Through this law, the positive law in Indonesia applies the criminal punishment for destruction and abuse of environment. Similarly, Islam forbids people do mischief on the earth, and Muslim scholars set criminal punishments in the form of $t a^{\prime}$ 'it for wrecking environment. Based on the opinion of Muslim scholars, it can be drawn a conclusion that the determination of punishment for wrecking the environment in positive law is in line with the provisions of Islamic law on ta'zir.
\end{abstract}

Keywords: management, environment, Islamic law; Law No. 23/1997, punishment

\section{A. Pendahuluan}

Manusia dan lingkungan hidup memiliki keterkaitan yang tidak dapat dipisahkan antara satu dengan lainnya.
Hal ini disebabkan karena manusia adalah bagian dari lingkungan hidup itu sendiri. Relasi yang demikian merupakan perwujudan dari ekosistem yang menjaga 
keseimbangan dan keselarasan antara satu dengan yang lainnya. Penjelasan dalam Undang-Undang No. 23 Tahun 1997 tentang Pengelolaan Lingkungan Hidup, khususnya pada bab 1 tentang ketentuan umum pasal 1 ayat 1 menyebutkan bahwa: "lingkungan hidup adalah kesatuan ruang dengan semua benda, daya, keadaan, dan makhluk hidup termasuk manusia dan perilakunya, yang mempengaruhi kelangsungan perikehidupan dan kesejahteraan manusia serta makhluk lain"'

Terkait dengan pentingnya menjaga lingkungan hidup, banyak sekali para ahli yang telah menuangkan gagasan, pikiran dan kemampuannya dalam megkaji dan menganalisis upaya untuk mewujudkan kehidupan manusia yang selaras dengan lingkungan. Pemerintah sendiri dalam hal ini juga telah mengeluarkan Undang-Undang tentang Pengelolaan Lingkungan Hidup yakni Undang-Undang No.23 Tahun 1997. Undang-Undang tersebut pada pokoknya memuat ketentuan-ketentuan umum tentang pengelolaan lingkungan hidup, serta rangsangan dan hukuman bagi pelanggaran mutu lingkungan hidup. $^{2}$

Manusia merupakan faktor dominan dan memiliki pengaruh terhadap baik buruknya sebuah komunitas lingkungan hidup karena tindakan manusia atas lingkungannya dapat berakibat positif-konstnkifi, atau sebaliknya dapat pula berakibat negativedestruktif. Dengan melihat adanya hal tersebut, maka untuk menjaga kelestarian lingkungan hidup, disahkanlah UndangUndang yang memuat ketentuan pidana bagi siapa saja yang tindakannya dapat mengancam kelestarian lingkungan hidup yang tertuang dalam Undang-Undang No. 23 Tahun 1997 pasal 41 ayat 1 dan 2.

Dalam konteks ajaran Islam, banyak sekali ayat-ayat al-Qur'an yang memerintahkan agar manusia menjaga kelesterian lingkungan hidup dan tidak merusaknya. Misalnya dalam surat alA'raf (7): 56 Allah berfirman:

"Dan janganlah kamu membuat kerusakan di muka bumi dengan melakukan kemusyrikan dan perbuatanperbuatan maksiat (sesudah Allah memperbaikinya) dengan cara mengutus rasul-rasul (dan berdoalah kepada-Nya dengan rasa takut) terhadap siksaan-Nya (dan dengan penuh harap) terhadap rahmat-Nya. (Sesungguhnya rahmat Allah amat dekat kepada orang-orang yang berbuat baik, yakni orangorang yang taat).

Tidak ada nas baik al-Qur'an maupun al-Hadist yang secara eksplisit memberikan sanksi kepada seorang yang telah merusak dan mencemari lingkungan hidup. Hal ini mengakibatkan munculnya beberapa pertanyaan bagaimana pandangan hukum Islam terhadap pelaku perusak dan pencemar lingkungan hidup? Bagaimana pula pandangan hukum Islam terhadap adanya ketentuan pidana dalam pasal 41 Undang-Undang No.23 tahun 1997? Artikel ini mencoba menganalisis secara filosofi terhadap masalah- masalah tersebut.

\section{B. Pengelolaan dan Kebijakan Pemerintah Bagi Perusak Lingkungan Hidup \\ Pembangunan nasional} dilaksanakan untuk mewujudkan Tujuan Nasional seperti termaktub dalam Pembukaan UUD 1945 alinea IV, yaitu ...... melindungi segenap bangsa Indonesia dan selumi tumpah darah Indonesia, memajukan kesejahteraan umum, mencerdaskan kehidupan bangsa, dan ikut melaksanakan ketertiban dunia yang berdasarkan kemerdekaan, perdamaian abadi, dan keadilan sosial serta mewujudkan cita-cita bangsa sebagaimana termaktub dalam alinea II Pembukaan UUD 1945." 
Salah satu sasaran pembangunan dalam bidang ekonomi adalah pemanfaatan lingkungan hidup dengan tidak mengesampingkan mutu dan fungsi lingkungan bagi kelangsungan hidup manusia beserta segenap makhluk hidup lainnya. Oleh sebab itu pemanfaatan sumber daya alam serta pengelolaannya harus didasarkan pada nilai manfaat yang sebesar- besarnya bagi pembangunan dan kesejahteraan rakyat, baik di masa sekarang maupun di masa yang akan datang.

Mengingat betapa pentingnya lingkungan hidup bagi keberlangsungan hidup manusia dan yang lainnya serta untuk menjaga agar pemanfaatan pengelolaan sumber alam dan lingkungan hidup dapat selaras dengan cita-cita pembangunan nasional, maka pemerintah mengeluarkan Undang-Undang No.23 Tahun 1997 yang mengatur tentang ketentuan-ketentuan pokok pengelolaan lingkungan hidup. Pengertian dari pasal 1 ayat 1 adalah agar usaha pengambilan manfaat atas semua sumber daya yang telah disediakan oleh lingkungan hidup tidak sampai menimbulkan efek negatif bagi kehidupan manusia, termasuk juga terhadap makhluk-makhluk hidup yang lain.

Kegiatan yang paling besar andilnya dalam usaha pemanfaatan sumber daya alam dan lingkungan hidup adalah bidang industri, terutama dalam era teknologi seperti sekarang ini. Kegiatan industri yang tidak terkontrol terutama dalam hal mengeksplorasi lingkungan hidup dapat berakibat buruk bagi alam dan manusia sendiri. Industrialisasi adalah usaha-usaha pemanfaatan kemajuan tekhnologi dengan lebih memanfaatkan kekayaan alam dan sumber-sumber yang dimiliki oleh alam.

Adanya industrialisasi sebagai suatu kegiatan untuk memanfaatkan sumber daya alam dan lingkungan hidup bukan berarti tidak ada pihak-pihak lain yang dapat memanfaatkan bahkan sampai membuat terjadinya ketidakseimbangan dalam lingkungan hidup, pihak-pihak lain tersebut dapat pula berupa seseorang atau beberapa kelompok orang yang bukan sebagai badan hukum. Kegiatan mengelola lingkungan hidup tidak hanya mengambil manfaat semata dari sumber daya alam dan lingkungan hidup, tetapi harus di ikuti dengan menata, memelihara, mengawasi, mengendalikan dan menjaga kelestarian lingkungan hidup.

Pengelolaan lingkungan hidup tidak hanya mengedepankan perolehan hak, namun secara implisit terkandung adanya tanggung jawab dan kewajiban terhadap lingkungan itu sendiri. Kewajiban perorangan meliputi memelihara lingkungan hidup sebagai tindakan prefentif dan menanggulangi pencemaran dan pengrusakan lingkungan hidup yang telah terjadi sebagai tindakan represif. Kewajiban perusahaan meliputi kewajiban memelihara kelestarian lingkungan hidup dan kewajiban membuat analisis dampak lingkungan.

Sedangkan kewajiban pemerintah adalah menentukan kebijaksanaan dan melakukan tindakan terhadap setiap upaya yang mendorong pelestarian lingkungan hidup demi menunjang pembangunan yang berkesinambungan, kewajibaan menumbuh kembangkan kesadaran masyarakat akan tanggung jawab pengelolaan linkungan hidup baik melalui penyuluhan ataupun bimbingan serta kewajiban membuat analisis dampak lingkungan dalam hal- hal tertentu. ${ }^{4}$

Secara umum Soemarwoto ${ }^{5}$ mengungkapkan bahwa masalah lingkungan di Indonesia dapat dibagi menjadi tiga kategori, yaitu: (1) masalah lingkungan udara, (2) masalah lingkungan darat, (3) masalah lingkungan air. Dari ke tiga permasalahan tersebut apabila dijabarkan lebih lanjut dapat diuraikan menjadi: masalah dalam pembangunan pertanian tanaman pangan, 
masalah dalam pembangunan perkebunan, masalah dalam pembangunan kehutanan, masalah dalam pembangunan perikanan kelautan, masalah dalam pembangunan industri, masalah dalam pencemaran air, masalah dalam pencemaran udara, masalah dalam perkembangan penduduk, masalah dalam pembangunan permukiman dan masalah dalam perkembangan teknologi.

Masalah lingkungan yang disebabkan dari penyalahgunaan lingkungan hidup atau merusak lingkungan hidup dapat dikenakan pidana dengan ketentuan yang dijelaskan pada bab IX pasal 41 Undang-Undang No. 23 Tahun 1997 yang menyebutkan sebagai berikut:

1. Barang siapa yang secara melawan hukum dengan sengaja melakukan perbuatan yang mengakibatkan pencemaran dan/atau perusakan lingkungan hidup, diancam dengan pidana penjara paling lama sepuluh tahun dan denda paling banyak Rp.500.000.000,00 (lima ratus juta rupiah).

2. Jika tindak pidana sebagaimana dimaksud pada ayat mengakibatkan orang mati atau luka berat, pelaku tindak pidana diancam dengan pidana penjara paling lama lima belas tahun dan denda paling banyak Rp750.000.000,00 (tujuh ratus lima puluh juta rupiah

\section{Ketentuan Pidana Pasal 41 Undang-Undang No. 23 Tahun 1997 dalam Perspektif Hukum Islam.}

Perbuatan tindak pidana dalam hukum Islam disebut sebagai jarimah, yaitu larangan-larangan syara' yang diancam oleh Allah dengan ancaman had atau ta'zir. Adapun unsur-unsur sebuah perbuatan dapat dikategorikan sebagai jarimah adalah sebagai berikut:

1. Adanya nas yang melarang perbuatan tersebut dan mengancam hukuman terhadapnya, unsur ini biasanya disebut unsur formil (nikin syar'i);

2. Adanya perbuatan yang termasuk jarimah, baik berupa perbuatanperbuatan nyata ataupun sikap tidak berbuat, unsur ini biasanya disebut unsur materiil (rukun māddh);

3. Pelaku adalah orang mukallaf, yaitu orang yang dapat dimintai pertanggung jawaban terhadap jarimah yang diperbuatnya, unsur ini biasanya disebut dengan unsur moril (nikun adabi).

Apabila seseorang melakukan suatu perbuatan yang termasuk jarimah, maka ia akan dikenai uqubahnya. Jika dalam hukum positif (KUHP) terdapat dua macam pembagian mengenai, tindak pidana, yaitu tindak pidana kejahatan dan tindak pidana pelanggaran, maka dalam hukum pidana Islam (jarimah) para ulama berbeda pendapat. Abdul Qadir Audah membagi jenis pidana menjadi tiga bagian, yaitu: jarimah hudind, jarimah qișass, dan divat serta jarimah ta'zir. Al- Mawardi dan Ahmad Fathu Bahsansi membagi jarimah menjadi dua yaitu: hudud dan ta'zir." Ahmad Zahroh berpendapat seperti halnya ulama' terakhir akan tetapi memakai istilah mahdüdah (hukuman yang di tentukan) dalam hal ini meliputi had dan qișass, sedang yang kedua adalah ghaini mahdiudah (hukuman yang tidak ditentukan yaitu berupa $t a$ ' $\overline{z i})$.

Dapat disimpulkan dari pendapat tentang pembagian hukum di atas, bahwa jenis hukum itu ada dua, yaitu hudud dan ta' $\overline{\text { IT }}$, hal ini karena hukuman qisas dan diyat adalah jenis hukuman yang terdapat ketentuan hukumnya di dalam nas, oleh karenanya hukuman qisas dan diyat tergolong hukuman hudisd. Apabila pengertian hudud dan had, menurut Ibrahim Halaby, sebagaimana dikutip oleh Haliman adalah hukuman yang tertentu, (muqaddarah) yang dijelaskan dalam al-Qur'an, al-Sunnah serta ijma'. Hukuman ini wajib ditegakkan oleh seorang Imam apabila sudah terpenuhi 
bukti-buktinya secara meyakinkan. ${ }^{10}$ Menurut ibn Hazm yang termasuk jarimah ini adalah riddah, pemberontakan, zina, menuduh zina, minum minuman keras, mencuri dan pengacau."

Ta'Zir adalah hukuman yang tidak dijelaskan hukumannya, artinya nas secara nyata tidak menyebutkan ketentuan hukumnya melalui jenis perbuatan maupun kadar ketentuan hukumnya (uqubahnya). Tentang ta'zir ini Islam memberikan porsi yang luas dengan demikian prinsipnya diserahkan kepada penguasa atau para hakim dalam menentukan ketentuan hukumnya. ${ }^{12}$

Terhadap perbuatan pidana (delik) penyalahgunaan lingkungan hidup, sebagaimana pada bahasan di atas yang termaktub dalam ketentuan pidana pasal 41 Undang-Undang No.23 Tahun 1997, bahwa delik kategori ini merupakan peristiwa pidana baru yang timbul pada hukum Islam, maka sudah barang tentu ketentuan hukumnya tidak didapatkan pada nas al-Qur'an maupun al-Sunnah. Dengan demikian, perbuatan pidana sebagaimana diformulasikan dalam pasal 41 Undang-Undang ini berdasarkan pada pengertian uqubah (hukuman) yang ada, yakni dapat ditetapkan sebagai jarimah yang dapat dijatuhi hukuman ta' Zir. Dengan demikian, segala yang bersangkut paut dengan ta'zir diserahkan sepenuhnya kepada para penguasa atau hakim.

Mengenai permasalahan bahwa orang yang meliputi orang-perorangan, kelompok atau badan hukum yang dapat dituntut hukuman bila terbukti secara legal menyalahgunakan pengelolaan lingkungan hidup adalah merupakan konsekuensi dan wewenang penguasa atau hakim yang diserahi sepenuhnya dalam masalah ta'zir ini. Sebab, hukum Islam juga memandang bahwa apakah perbuatan itu dilakukan oleh seseorang atau kelompok atau badan hukum, selama perbuatan tersebut dapat membahayakan kemaslahatan umum, maka boleh saja dijatuhi hukuman. Hal ini didasarkan pada tujuan pemberlakukan hukum Islam yaitu mewujudkan kemaslahatan umum.

Diserahkannya ketentuan hukum ta'zir kepada para penguasa atau hakim adalah agar dapat disesuaikan dengan adat istiadat (urf) dan kondisi sosial setempat, sehingga persoalan ta'zit membuka seluas-luasnya pintu ijtihad bagi para ulama. ${ }^{13}$ Berkenaan dengan ketentuan hukuman yang tercantum dalam pasal 41 Undang-Undang No 23 Tahun 1997 yaitu berupa pidana penjara dan atau denda dengan ketentuan maksimal yang telah ditetapkan dalam pasal tersebut, maka ini juga dimasukkan dalam lapangan ijtihad bagi para ulama untuk penyetujui atau tidak menyetujuinya.

Dalam diskursus usul fikih, sebuah permasalahan dikategorikan ijtidadi atau bukan memiliki beberapa ketentuan, yaitu:

1. Lapangan hukum yang dibawa oleh nas yang qat' $i$ kedudukannya dan qat' $i$ pengertiannya. Nas yang semacam ini hanya terdapat dalam al-Qur'an dan al-Hadist mutawatir. Masalah obyek ijtihad disini hanyalah dari segi pengertiannya saja, yakni kedudukan hukum yang dipandang.

2. Lapangan hukum yang dibawa oleh nas yang zhanni kedudukannya, tetapi qat' $i$ pengertiannya, nas yang semacam ini hanya terdapat dalam alHadits. Obyek ijtihad dalam hal ini adalah harus meneliti dari segi sanad dan matan hadits.

3. Lapangan hukum yang terdapat dalam nas yang zhanni baik dari segi kedudukannya ataupun dari segi pengertiannya. Objek Ijtihad dalam hal ini adalah menemukan hukum.

4. Lapangan hukum yang tidak ada nasnya sama sekali. Dalam bidang ini seorang mujtahid bebas untuk melakukan ijtihad dan tidak terikat untuk menemukan dan menentukan suatu hokum. Dalam berijtihad seorang mujtahid dapat menggunakan 
bermacam-macam metode antara lain: metode analogi (qiyas), masalah mursalah, istihsan atau yang lainnya.

Dalam hal ketentuan pidana dan kadar hukuman terhadap penyalahgunaan pengelola lingkungan hidup ini, maka masalah ini masuk pada jenis ijtihad yang nomer dua. Lapangan ijtihad disini luas sekali, sebab, nas al-Qur'an atau al-Hadis yang mengaturnya tidak telalu banyak. Beberapa nas tersebut antara lain: Ala'raf (7): 56, al-'Ankabut (29): 36, alSyura (42): 183, al-Qasas (28): 77 dan alRum (30): 41. Dalam sebuah hadis Nabi juga melarang untuk berbuat yang menimbulkan bahaya yang artinya: "tidak boleh membuat kemudharatan dan membalas dengan kemudharatan yang sama" (HR. Ibnu Majah).

Berdasarkan beberapa dalil yang ada ini dapat diberlakukan kaidah yang: "menumt aslinya larangan itu berarti mengharamkan".14 Dari kesimpulan kaidah ini maka berbuat kerusakan di bumi dapat dipahami sebagai hal yang diharamkan. Larangan ini membuahkan pengertian agar manusia melakukan perbuatan yang terpuji dalam mengelola bumi sebagai sarana untuk melindungin kelangsungan kehidupan manusia itu sendiri.

Kaidah lain yang juga tepat dalam masalah ini adalah: "Tidak dapat diingkari adanya penibahan hukum karena benubahnya masa." "Kaidah ini Menunjukkan betapa Islam sebagai hukum membuka peluang untuk dilakukannya suatu perkembangan dan perubahan yang didasarkan pada kemaslahatan. Dalam konteks ini umat Islam perlu mendukung upaya pemerintah untuk membangun tegaknya hukum baik melalui kodifikasi, unifikasi atau penyusunan perundang-Undangan baru yang sangat dibutuhkan dalam upaya mendukung pembangunan di berbagai bidang.

Para ulama tidak bersepakat tentang masalah kadar dan hukuman $t a$ 'Zit, ada yang berpendapat bahwa ta' $\bar{Z} \bar{r}$ tidak boleh lebih dari 10 kali cambuk (pendapat dari Ahmad), ada juga yang mengatakan bahwa ta'zir tidak boleh kurang dari hukuman had yaitu 40 atau 80 kali cambuk ( pendapat sebagian madzhab al- Syafi'I, Abu Hanifah dan Ahmad). Ada juga yang berpendapat bahwa kadar hukuman ta'zir disesuaikan menurut kemasalahatan dengan mempertimbangkan tingkat kejahatan yang dilakukan. ${ }^{16}$

Berdasarkan pendapat para ulama' ini, maka dapat ditarik suatu kesimpulan bahwa ketentuan ta'zir memang tidak disebutkan di dalam nas. Dengan demikian peluang untuk dilakukannya ijtihad menjadi terbuka lebar. Meskipun demikian, dalam menentukan kadar dan jenis ta'zir (hukuman) harus didasarkan pada kemaslahatan masyarakat.

Ta'Zir merupakan landasan yang kuat dan sumber yang penting bagi peletakan Undang-undang kriminal, yang penetapan hukumnya didasarkan pada kadar dan kondisi kejahatan, baik pada pelaku, korban, tempat serta waktu terjadinya kejahatan. ${ }^{17}$

Tindakan pemerintah dalam menetapkan kadar dan jenis pidana terhadap seseorang atau siapa saja yang melakukan sesuatu perbuatan yang dapat membahayakan keselamatan lingkungan dengan akibat tercemar dan rusaknya lingkungan tersebut, baik dilakukan dengan sengaja maupun tidak (lalai), pada hakikatnya telah disesuaikan dengan kondisi, waktu dan kepentingan saat ini.

\section{Ketentuan Pidana Pasal 41 Undang-Undang No 23 Tahun 1997 dalam Perspektif Filsafat Hukum}

Untuk menjelaskan masalah di atas maka berikut akan dijelaskan beberapa aliran dalam filsafat hukum relevan untuk mengkaji persoalan yang ada. Aliran yang pertama adalah aliran positivisme. Aliran ini memandang bahwa antara hukum dan moral harus dipisahkan (antara hukum yang berlaku dan hukum yang seharusnya). Aliran ini 
dapat dibedakan menjadi dua corak: (1) aliran hukum positif analitis yang di pelopori oleh John Austin. (2) aliran hukum murni yang dipelopori oleh Hans Kelsen.

Menurut Austin, hukum adalah perintah dari penguasa Negara, lebih jauh dia mengatakan bahwa superior itulah yang menentukan apa yang diperbolehkan dan apa yang tidak diperbolehkan. Dalam perspektif ini dapat dikatakan bahwa kekuasaan superior dapat memaksa orang lain untuk taat serta hukuman adalah perintah yang memaksa, bisa bijaksana, adil atau sebaliknya, ${ }^{18}$ Austin membagi hukum menjadi dua: (1) hukum dari Tuhan untuk manusia (2) hukum yang dibuat manusia. Tentang hukum yang dibuat manusia ini ada yang merupakan hukum yang sebenarnya (disebut hukum positif) yaitu meliputi hukum yang dibuat penguasa dan hukum yang disusun oleh manusia secara individu untuk melaksanakan hakhak yang diberikan kepadanya. Adapun hukum yang kedua dianggap sebagai hukum yang tidak sebenarnya yaitu hukum yang tidak dibuat oleh penguasa, sehingga tidak memenuhi persyaratan sebagai hukum seperti ketentuan dari suatu organisasi olah raga. Hukum yang sebenarnya harus memenuhi persyaratan: (1) Adanya unsur perintah; (2) Adanya unsur sangsi; (3) Adanya unsur kewajiban; dan (4) Adanya unsur kedaulatan.

Sedang menurut Kelsen hukum harus dibersihkan dari analisis yang non yuridis, seperti sosiologis, politis, historis bahkan etis. Hukum adalah suatu keharusan yang mengatur tingkah laku manusia sebagai makhluk rasional. Keadilan sebagai isi hukum berada di luar hukum. Disisi lain Kalsen mengakui bahwa hukun positif pada kenyataannya dapat saja menjadi tidak efektif lagi, hal ini karena kepentingan masyarakat yang diatur sudah tidak ada, dan biasanya dalam keadaan demikian penguasa pun tidak akan memaksakan penerapannya. ${ }^{19}$
Dengan melihat pendapat diatas, maka pasal 41 Undang-Undang No 23 tahun 1997 dapat digolongkan sebagai hukum positif hal ini karena disamping hukum ini dibuat oleh penguasa juga memenuhi kreteria yang dikemukakan oleh Austin yaitu adanya keempat unsur di atas, hukum ini termasuk kategori hukum yang di buat oleh manusia yang sebenarnya.

Sedang unsur keadilan harus terpisah dari isi hukum itu maka disini tidak dapat berlakukan, karena unsur keadilan itu yang seharusnya menjadi isi dari Undang-Undang ini. Adapun moral dalam pelaksanaan hukum ini adalah nilai moral yang dianggap paling tinggi di masyarakat.

Aliran yang kedua adalah aliran utilitarianisme. Aliran ini meletakkan kemanfaatan sebagai tujuan utama hukum. Kemanfaatan diartikan sebagai kebahagiaan. Jadi, baik buruk atau adil tidaknya suatu hukum tergantung kepada apakah hukum itu memberikan kebahagiaan kepada manusia atau tidak. ${ }^{20}$

Kebahagiaan ini selayaknya dapat dirasakan oleh setiap individu dalam masyarakat. Bentham berpendapat bahwa alam memberikan kebahagiaan dan kesusahan. Manusia selalu memperbanyak kebahagiaan dan mengurangi kesusahannya. Kebaikan adalah kebahagiaan dan kejahatan adalah kesusahan, tugas hukum adalah memelihara kebaikan dan mencegah kejahatan. Selanjutnya Bentham berpendapat bahwa pembentuk UndangUndang hendaknya dapat melahirkan Undang-Undang yang mencerminkan keadilan bagi semua individu. Dengan berpegang pada prinsip tersebut, perundang-Undangan itu hendaknya dapat memberikan kebahagiaan. Selain Jeremy Bentham tokoh aliran ini adalah John Stuart Mill. Mill mempunyai pandangan yang sama dengan Jeremy, kesamaan pendapat itu terletak bahwa suatu perbuatan itu hendaknya bertujuan 
untuk mencapai sebanyak mungkin kebahagiaan.

Dilihat dari berbagai pendapat tersebut di atas maka sebenarnya hukum pidana pasal 41 Undang-Undang No 23 tahun 1997 mempunyai persamaan visi, hal ini karena diberlakukannya hukum ini agar lingkungan hidup ini masih terjaga dan lestari serta dapat dimanfaatkan sebanyak-banyaknya bagi manusia. Hal ini tentunya tidak mungkin dapat tercapai jika tidak ada aturan yang mengatur bagaimana mengelola lingkungan hidup dan tindak pidana bagi yang melakukan pengrusakan lingkungan hidup atau ekosistem yang ada. Seandainya tidak ada aturan yang mengatur tentang tata cara pengelolaan lingkungan hidup maka setiap orang akan melakukan eksplorasi sebebas-bebasnya demi memenuhi semua kebutuhannya tanpa memperdulikan orang lain.

\section{E. Penutup}

Islam adalah agama yang membawa rahmat bagi alam semesta dan sangat peduli terhadap pengelolaan lingkungan. Karena itu, pengelolaan lingkungan hidup seharusnya memperdulikan kemanfaatan bagi orang banyak tanpa mengesampingkan mutu

\section{Catatan Akhir:}

I Undang-Undang Republik Indotnesia Nomor 23 Tahun 1997 tentang Pengelolaan Lingkungatn Hidup.

JPN. Siragih S Sistortus, Bumga Rampai Lingkangan Hidup ( Surabaya: Usaha Nasional, t.t.), hlm. 146 .

Lihat Pembukaan Undang-Undang Dasar 1945 Alinea IV.

4 Abdumahmatn, Pengantar Hakw Lingkungan Hidup Indonesia (Bandung: Penerbit Ani 1986), hlm. 64-65.

Soemarwotto Otto, Masalah Lingkumgan Nasional Dan Global, Sebuah Mhiar Menbangum Tampa Mensak Linghungan (Jakarta: Katitor Metiteri Negara Lingkungatı Hidup, 1994, hlm. 12. dan fungsi lingkungan bagi kelangsungan hidup manusia beserta segenap makhluk hidup lainnya.

Mengingat betapa pentingnya lingkungan hidup bagi kelangsungan hidup manusia beserta makhluk hidup lainnya dan untuk menjaga agar pemanfaatan pengelolaan sumber alam dan lingkungan hidup dapat selaras dengan cita-cita pembangunan nasional, maka pemerintah mengeluarkan UndangUndang No.23 Tahun 1997 yang mengatur tentang ketentuan-ketentuan pokok pengelolaan lingkungan hidup.

Masalah lingkungan yang disebabkan dari penyalahgunaan lingkungan hidup atau merusak lingkungan hidup dapat dikenakan pidana dalam agama Islam yang dikenal dengan nama jarimah yaitu larangan-larangan syara' yang diancam oleh Allah dengan ancaman hadd atau ta' 7 ir.

Sementara itu, dalam pandangan filsafat hukum tindak pidana ini termasuk hukum positif. Hukum tersebut diberlakukan untuk menjaga kelestarian lingkungan hidup sehingga lingkungan hidup yang lestari dapat dimanfaatkan bagi generasi berikutnya.

6 Ahmad Hanafi, Asas-Asas Hukwn Pidana Islan (Jakarta: Bulan Bintang, 1986), hlm. 6 .

7 Abdul Qadir' 'Awdah, 1/-Tasy' $a /$ Jina'i a/Is/ami (Bairut: Dār al-Ghurabāh, t.th.), hlm. 78 .

Al-Mawardi, $\quad 1 /-1 / k \bar{k} m$ asSu/hälyyah wa a-Wihyah al ad-Dinivah (Mesit: tnp., 1973), hlm. 221. Lihat juga Ahmad Fathu, A/-Uqübh fi a/-Figh a/-Is/am (Bairut: Dā" alGhurabāh, 1961), hlm. 18.

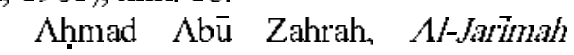
(Bairut: Dār Al-Fikri, 1976), hlm. 63.

10 Haliman, Hakwm Pidana Syariat Islam memmu Ahhssumah (Jakarta: Bulan Bittatig, 1971), hlm. 375.

"I Ibn Hazm, $1 /-M w h / \bar{a}$ Bairut:

Yaktabah at-Tijärian t.th.), hlm. 373. 
${ }^{12}$ Untuk mengetahui defenisi ta'zir bisa di lihat $\Lambda$ bu Zahrah, Al-Jarimah, hlm. 123 dan 'Awdah, Af-TasyTh', hlm. 680.

${ }_{13}^{3}$ Hasbie as-Shiddieqy, Falsafah Hakam Islam (Jakarta: Bulan Bintang, 1988), hlm. 101 dan 135.

${ }^{14}$ Al-Suyựi, A/-Asybăh wa ant-Nazar 'it (Bairut: Dār al-Fikr, t.th.), hlm. 35.

${ }^{15}$ Asmuni Abdumahman, Kaidah-Kaidah Figh (Jakarta: Bulan Bintang, 1976), hlm. 107.

${ }^{16}$ As-Shiddieqy, Filsafat, hlm. 136-137.

${ }^{17}$ Muhmüd Syalțūt, $1 /$-Is/äm Aqidah wa Syari 'ah (Mesir: Dār an-Nadah, t.th.), hlm. 234.

${ }_{18}$ Lyons D., Ethes And The Rule Of Law

(Cambrige: Cambrige Univercity Press, 1983), hlm. 7-8.

19) Darji Darmodiharjo, Pokok- Pokok Filsafat Hikhm (Jakatta: Gramedia, 1996), hlm. 113-115.

${ }^{3}$ Lili Rasjidi, Filsafat Hukum

(Bandung: Remaja Rosdakarya, 1988), hlm. 46.

\section{DAFTAR PUSTAKA}

Abdurrahman. Pengantar Hukum Lingkungan Hidup Indonesia. Bandung: Penerbit Ani, 1986.

Anonim. Ulama Intemasional Membahas Lingkungan Dalam Persfektif Islam. Bogor: Fakultas Kehutanan IPB, 2007.

Antariksa, S. Sebuah Pemasalahan di Dalam Lingkungan Hidup. Ttp.: Liberty, 1988.

Audah, Abdul Qadir. At-Tasyri' al-Jinä' al-Istāmi, Bairut: Dār alGhurābah, t.t.

Al-Māwardi. Al-Ahkām as-Sultāniyyah wa al-Wilayah ad-Diniyah. Mesir: tnp., 1973.

Abdurrahman, Asymuni. Kaidah-Kaidah Fiqh. Jakarta: Bulan Bintang, 1976.

As-Shiddieqy, Hasbie. Falsafah Hukum Islam. Jakarta: Bulan Bintang, 1988.

As-Suyūịi, Al-Asybāh wa an-Naza'ir. Bairut: Dār al-Fikr, t.t.
Darmodiharjo, Darji. Pokok- Pokok Filsafat Hukum. Jakarta: Gramedia, 1996.

Djamil, Fathurahman. Filsafat Hukum Islam. Jakarta: Logos Wacana Ilmu, 1997.

Fathu, Ahmad. A/-Uqübah fi a/-Fiqh a/Islāmi. Bairut: Dār al-Ghurābah, 1961.

Haliman. Hukum Pidana Syari'at Islam Menumut Ahlussunnah. Jakarta: Bulan Bintang, 1971.

Harahap, Adnan. Islam dan Lingkungan Hidup. Jakarta: Yayasan Suara Bhumy, 1997.

Hanafi, Ahmad. Asas-Asas Hukum Pidana Islam. Jakarta: Bulan Bintang, 1986.

Hazm, Ibn. A/-Muhallā. Bairut: Maktabah at-Tijārian t.t.

JPN, Siragih S Sistorus. Bunga Rampai Lingkungan Hidup. Surabaya : Usaha Nasional, t.t.

Lyons, D. Ethics and The Rule of Law: Cambrige: Cambrige University Press, 1983.

Al-Qardhawi, Yusuf. Islam Agama Ramah Lingkungan, terj. Abdullah Hakam Shah, dkk. Jakarta: Pustaka Al-Kautsar, 2002.

Rasjidi, Lili. Filsafat Hukum. Bandung: Remaja Rosdakarya, 1988.

Syalțūt, Muḥmūd. Al-Is/ān Aqīdah wa Syaríah. Mesir: Dār an-Nahḍah, t.t.

Soemarwotto, Otto. Masalah Lingkungan Nasional dan Global, Sebuah Ikhtiar Membangun Tanpa Menisak Lingkungan. Jakarta: Kantor Menteri Negara Lingkungan Hidup, 1994.

Undang-Undang Republik Indonesia Nomor 23 Tahun 1997 tentang Pengelolaan Lingkungan Hidup.

Undang-Undang Dasar 1945. 


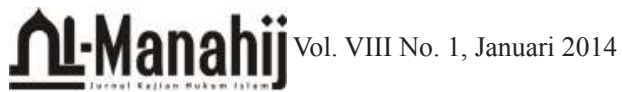

